\title{
Sinister portal hypertension
}

\author{
M. I. Tutchenko, S. L. Chub, D. V. Rudyk \\ Bogomolets National Medical University, Kyiv

\section{Сіністральна портальна гіпертензія} \\ М. І. Тутченко, С. Л. Чуб, Д. В. Рудик \\ Національний медичний університет імені О. О. Богомольця, м. Київ
}

Sinistral, left-sided, or segmental portal hypertension causes gastric hemorrhage in 3-15\% of patients and is often associated with compression of pancreatic veins, chronic pancreatitis, and splenic vein thrombosis [1-3]. In most patients, the course of the pathology is asymptomatic, it is detected when there is a complication, such as a hemorrhage. About $5 \%$ of patients with portal hypertension have sinistral portal hypertension [4], the main cause of which is an acute or chronic pancreatitis [5]. Unlike generalized hypertension, sinistral portal hypertension does not change the portal blood flow, the size of the portal hepatic vein, and the hepatic competence [6]. Accordingly, in the case of blockage of the splenic vein, megalosplenia and hypersplenism the pressure increased leads to development of spleno-portal collaterals, which are clinically presented by thrombocytopenia and hemorrhage from gastric varicosities [7]. The most effective treatment is considered to be the treatment of gastric varicosity, using sclerosant drugs [8]. Spleno-renal anastomosis can be successfully applied in the treatment of gastric hemorrhage with fundic distribution of varicose veins in patients with non-cirrhotic origin of portal hypertension [9]. Here is a clinical observation.

Patient A., 47 years old, was hospitalized for signs of gastro-enteric hemorrhage (severe anemia and melanorrhagia), which required the blood transfusion. Over the past 5 years, he had 21 hemorrhages, and was treated in hospitals, using resuscitation measures and the blood transfusion therapy. Endoscopic examination have shown multiple varicose veins of the fundal part of stomach with red spots, which corresponded to IGV1, according to classification of S. K. Sarin et al. [10].

Sonographic examination have shown normal hepatic size and structure, and the changes in the pancreas, corresponding to chronic pancreatitis, with the diameter of portal hepatic vein $14 \mathrm{~mm}$, the spleen vein - $10 \mathrm{~mm}$, and a spleen size $-20 \times 10 \times 8 \mathrm{~cm}$. Biochemical functional hepatic parameters were satisfactory. Anemia was pronounced: red blood cells $2.57 \times 10^{12} / 1$, hemoglobin $73 \mathrm{~g} / 1$, absolute PLT count $-46 \times 10 \% / 1$.

Laparotomy was performed. Hepatitis without macroscopic changes was present. Heavy adhesions were found between the stomach fundal part, an enlarged spleen and the diaphragm After performance of splenectomy, resection of the fundal part of the stomach was performed with multiple sclerosed veins, owing a diameter of 3-5 $\mathrm{mm}$. The veins were visualized after gastrotomy performance, what made it possible to extirpate them in full. Histologic examination of the spleen have revealed the red pulp hyperplasia.

The patient was discharged on the 9th postoperative day. Benign anemia have persisted for 6 months after surgery. Data from endoscopic examination have indicated the absence of gastric and esophageal varices, and a sonographic examination - a chronic pancreatitis phenomena. A platelet count have increased to $650 \times 10^{9} / 1$.

Understanding of vascular anatomy in patients with gastric varices helps to get positive treatment results and minimize the complications. Gastric veins are drained into the systematic circulation through the esophageal-paraesophageal varices (gastroesophageal venous system), the inferior phrenic vein (gastro-phrenic venous system), or into both of these basins [11]. These drainage options correspond to the classification of K. Sarin et al. [10], and if only 30\% of gastric varices are localized in the fundal part of stomach, they cause $70 \%$ of all gastric hemorrhages. In this regard, there is a necessity for appropriate treatment in patients with gastric varices. Initial actions include achieving of hemodynamic strength, administration of vasoactive drugs (somatostatin, terlipsin), antibiotics, and the blood transfusions in compliance with a restrictive policy $[4,12,13]$. In the future, sclerotherapy would be favorable, which is successful for hemor- 
rhages from gastric varices [8]. In a case of massive uncontrolled hemorrhage, the balloon swabbing with Sengstaken or Linton probes has a positive effect [14].

\section{Conclusions}

Sinistral portal hypertension is a particular factor in gastrointestinal hemorrhage. If in patients with megalosplenia, portal hypertension there is no chronic hepatitis, the presence of isolated gastric varices and repeated profuse hemorrhages, chronic pancreatic diseases should be considered as a pathogenetic factor of the disease. Resection of gastric fundus part, in which varicosities are located, causing hemorrhage, and splenectomy eliminates not only the source of a hemorrhage, but the pathological circle of systemic collaterals, existing in the patients with sinistral portal hypertension, as well.

Funding. No source of funding has been received for this work.

Autbors contribution. All authors made the same contribution to this article.

Competing interests. The authors have no conflict of interest.

Consent for publication. All authors approved the paper to be published.

\section{References}

1. Thompson RJ, Taylor MA, McKie LD, Diamond T. Sinistral portal hypertension. Ulster Med J. 2006 Sep;75(3):175-7. PMID: 16964806; PMCID: PMC1891772.

2. Sakorafas GH, Sarr MG, Farley DR, Farnell MB. The significance of sinistral portal hypertension complicating chronic pancreatitis. Am J Surg. 2000 Feb;179(2):129-33. doi: 10.1016/s00029610(00)00250-6. PMID: 10773149.

3. Ruzicka M, Konecna D, Jordankova E. Portal hypertension as a complication of chronic pancreatitis. Hepatogastroenterology. 1999 Jul-Aug;46(28):2582-4. PMID: 10522045.

4. Köklü S, Coban S, Yüksel O, Arhan M. Left-sided portal hypertension. Dig Dis Sci. 2007 May;52(5):1141-9. doi: 10.1007/s10620 006-9307-x. Epub 2007 Mar 24. PMID: 17385040.

5. Fernandes A, Almeida N, Ferreira AM, Casela A, Gomes D, Portela F, et al. Left-Sided Portal Hypertension: A Sinister Entity. GE Port J Gastroenterol. 2015 Oct 29;22(6):234-9. doi: 10.1016/j. jpge.2015.09.006. PMID: 28868415; PMCID: PMC5579986.
6. Kul M, Haliloğlu NÜ, Hürsoy N, Erden A. Sinistral Portal Hypertension: Computed Tomography Imaging Findings and Clinical Appearance-A Descriptive Case Series. Can Assoc Radiol J. 2018 Nov;69(4):417-21. doi: 10.1016/j.carj.2018.07.006. Epub 2018 Oct 11. PMID: 30318456.

7. Ru N, He CH, Ren XL, Chen JY, Yu FF, Yan ZJ, et al. Risk factors for sinistral portal hypertension and related variceal bleeding in patients with chronic pancreatitis. J Dig Dis. 2020 Aug;21(8):468-74. doi: 10.1111/1751-2980.12916. Epub 2020 Aug 4. PMID: 32584511.

8. Robles-Medranda C, Nebel JA, Puga-Tejada M, Oleas R, Baquerizo-Burgos J, Ospina-Arboleda J, et al. Cost-effectiveness of endoscopic ultrasound-guided coils plus cyanoacrylate injection compared to endoscopic cyanoacrylate injection in the management of gastric varices. World J Gastrointest Endosc. 2021 Jan 16;13(1):13-23. doi: 10.4253/wjge.v13.i1.13. PMID: 33520103; PMCID: PMC7809595.

9. Anand U, Kumar R, Priyadarshi RN, Parasar K, John AG. Proximal Splenorenal Shunt Surgery for Bleeding Gastric Varices in Non-Cirrhotic Portal Hypertension. Cureus. 2020 Sep 15;12(9):e10464. doi: 10.7759/cureus.10464. PMID: 33083167; PMCID: PMC7566982.

10. Sarin SK, Lahoti D, Saxena SP, Murthy NS, Makwana UK. Prevalence, classification and natural history of gastric varices: a longterm follow-up study in 568 portal hypertension patients. Hepatology. 1992 Dec;16(6):1343-9. doi: 10.1002/hep.1840160607. PMID: 1446890.

11. Chikamori F, Kuniyoshi N, Shibuya S, Takase Y. Correlation between endoscopic and angiographic findings in patients with esophageal and isolated gastric varices. Dig Surg. 2001;18(3):176-81. doi: 10.1159/000050126. PMID: 11464006.

12. Turon F, Casu S, Hernández-Gea V, Garcia-Pagán JC. Variceal and other portal hypertension related bleeding. Best Pract Res Clin Gastroenterol. 2013 Oct;27(5):649-64. doi: 10.1016/j.bpg.2013.08.004. Epub 2013 Sep 5. PMID: 24160925.

13. de Franchis R; Baveno V Faculty. Revising consensus in portal hypertension: report of the Baveno $\mathrm{V}$ consensus workshop on methodology of diagnosis and therapy in portal hypertension. J Hepatol. 2010 Oct;53(4):762-8. doi: 10.1016/j.jhep.2010.06.004. Epub 2010 Jun 27. PMID: 20638742.

14. Martínez-González J, López-Durán S, Vázquez-Sequeiros E, Albillos-Martínez A. Management of fundic varices. Endoscopic aspects. Rev Esp Enferm Dig. 2015 Jul;107(8):501-8. PMID: 26228954.

Received: 26.12 .2020 